IJLRES - International Journal on Language, Research and Education Studies

ISSN: 2580-6777 (p); 2580-6785 (e)

Vol. 1, No. 1, 2017

Page: 130 - 147

\title{
HEADMASTER POLICY OF SENIOR ISLAMIC SCHOOL TO INCREAS TEACHER PROFESIONALISM AT STATE SENIOR ISLAMIC SCHOOL 2 MODEL MEDAN
}

\author{
Muhammad Arifin Tanjung \\ Ministry of Religious Affairs of North Sumatra Province \\ email: m.arifin.tanjung@gmail.com \\ Fachruddin Azmi \\ State Islamic University of North Sumatra \\ Syafaruddin \\ State Islamic University of North Sumatra
}

\begin{abstract}
State Senior Islamic School 2 Model Medan oh of famous Islamic schools in North Sumatera. The issues in this writing are what are the formulation, organization, aplication and evaluation of headmaster Policy of Senior Islamic School to Increas Teacher Profesionalism at State Senior Islamic School 2 Model Medan. To explain the main issue in this writings, I have to observ and intervew the moeslem population. Data has been collected will be expalined detailly and analysed by Islamic education management. Based on research, formulation of headmaster Policy of Senior Islamic School to Increas Teacher Profesionalism at State Senior Islamic School 2 Model Medan is bottom upwhich ideas from teachers, beginning from teachers meeting in one subject, teachers meeting in one program, annual meeting in a month and annual meeting in a year, and finally in team work, for example anual teachers meeting, seminar, workshop, cofee morning, study comparation to university and other school. It will motivate teacher in teaching, activity and anythings. Besides it, headmaster facilitate everything what ever teacher need it, for example infocus, laptop and everyting. And organization of headmaster Policy of Senior Islamic School to Increas Teacher Profesionalism at State Senior Islamic School 2 Model Medan is cooperation with school commite and he helped by vices and head program and teachers and chairman of student. The special of school organization are evaluation of teachers activity and relation to abroad. Headmaster states his potition as teacher who teach students, leader who leads teachers, manager who manages, motivator who motivate, supervisiorwho sipervise teachers activity, and facilitator for teachers. And finally evaluation of headmaster Policy of Senior Islamic School to Increasethe Teacher Profesionalism at State Senior Islamic School 2 Model Medan each level, begginning from teachers meeting in one subject, teachers meeting in one program, annual meeting in a month and annual meeting in a year, and finally in the team work as formulation of policy. The teachers have responsibility of ideas and program.
\end{abstract}

Key Words: Headmaster Policy, Teacher Profesionalism, State Senior Islamic School 2 Model Medan

\section{INTRODUCTION}

The ideal principal of Madrasah should be able to synergize management capability and leadership ability simultaneously. At the level of interaction behavior 
between organizational man and empowerment of supporting resources, the two capabilities are difficult to separate, because the praxis of leadership and management is not easily distinguished. ${ }^{1}$ The head of Madrasah is responsible for running the Madrasah organization's wheel. The function of the Madrasah principal as well as the manager is also a thinker and developer. His task within this framework is to think about the progress of Madrasahs. The principal of Madrasah is demanded for professionals who are well qualified to work above the average of other personnel in Madrasah, and have a high moral commitment to his work in accordance with his professional code of ethics. ${ }^{2}$

The reality on the ground shows that many Madrasahs with low student learning achievement, teachers and students are less disciplined, the ability of teachers in managing low learning, and the slowness of administrative staff in serving the needs of students and teachers. These problems are a reflection of the lack of ability of Madrasah or Head of Madrasah in empowering its staff, in addition to the low work ethic of the Madrasah community as a whole. Head of Madrasah s should be able to manage resources in Madrasah effectively and efficiently to achieve educational goals. ${ }^{3}$

To obtain the head of a Madrasah or a Madrasah capable of performing its role well, the candidate head of Madrasah as recommended by the Educational Leadership Costituent Council must meet the following standards:

1. Ability to promote student success;

2. Ability to promote Madrasah culture;

3. The ability to manage resources;

4. Ability to cooperate / collaborate;

5. Ability to carry out integrated, honest and ethical action;

6. The ability of high response power to social, political, economic and cultural values. And;

7. Ability in internship / work practices. ${ }^{4}$

${ }^{1}$ SudarwanDanimdanSuparno, Manajemen dan Kepemimpinan Transformasional Kekepala Sekolaha; Visi dan Strategi Sukses Era Teknologi, Situasi Krisis dan Internasionalisasi Pendidikan (Jakarta: Rineka Cipta, 2009), p. 1-4.

${ }^{2}$ Ibid.

${ }^{3}$ Ibid. 
If the seven standards set out above are met, then the predetermined shared vision will be well achieved and the leadership of the Madrasah principal will be effective. Therefore, during the recruitment of the head of Madrasahs have to be careful not to nominate the candidates of Head of Madrasah who do not have the competence to graduate into the head of Madrasah. ${ }^{5}$

Head of Madrasah is one of the human resources that include the scope of educational administration. To achieve educational objectives productively in the micro context, the role of professional Head of Madrasah is very important. Therefore the performance of Madrasah principal should be improved. Only the head of Madrasah, who has good performance, Can be productively achieved. ${ }^{6}$

The existence of Head of Madrasah is very strategic especially in educational institution. The head of the Madrasah is at the forefront of ensuring the quality of Madrasah under his responsibility. In addition, the leadership culture in Indonesia is patrilineal, that is, the policy changes made by the superior to the subordinate (topdown). In summary, if the leader has a high innovation will be positive for the institution he leads. This phenomenon is interesting to be researched further in the area of professional quality development policy of Madrasah principal especially in MAN 2 Medan. This Madrasah is very important because of some uniqueness owned by Madrasah AliyahNegeri 2 Medan Model among others in terms of human resources (HR) of the educator in MAN 2 Model Medan background of Strata 2 (Magister) and has head of Madrasah with educational background Strata 3 (Doctorate). In addition, this Madrasah mentions itself as a model Madrasah for the North Sumatra Province.

The uniqueness of Madrasah AliyahNegeri 2 Model Medan with the ability of Head of Madrasah to lead the teacher is very interesting to be studied. On the one hand all policies of the Head of Madrasah are regulated, on the other hand he also has the authority to innovate and be creative in order to realize a quality educational environment. A quality education environment will not be separated from teachers who are directly dealing with students. Qualified teachers will be able to produce learners who are independent, personable and also innovate. Therefore, to realize a

4Budi Suhardiman, Studi Pengembangan Kepala Sekolah; Konsep dan Aplikasi (Jakarta: Rineka Cipta, 2012) , p. 4.

5 Ibid.

${ }^{6}$ Suhardiman, Studi Pengembangan..., p. 179. 
professional teacher so as to produce qualified learners should be led by the head of Madrasah who has the leadership of the institution of education. In this case Madrasah AliyahNegeri 2 Model Medan very worthy of research with the ability to obtain national and local achievements.

\section{LITERATURE REVIEW}

\section{Policy and Head of Madrasah}

Policy is a translation of a policy word that comes from English.Kata policy is defined as an activity plan or statement about the goals, proposed or adopted by a government, political parties, and etc.The policy is also interpreted as statements regarding Guarantee contract or written statement. This definition implies that the so-called policy is about a plan, statement of purpose, contract of guarantee and a written statement whether issued by the government, political parties, and etc. Therefore anyone can be related in a policy.

James E. Anderson provides a policy definition as a series of actions that have a specific purpose followed and implemented by a perpetrator or a group of actors to solve a particular problem. This understanding provides an understanding that the policy can come from a perpetrator or a group of actors that contains a set of actions that have a specific purpose. This policy is followed and implemented by a principal or a group of actors in order to solve a particular problem.

James E. Anderson more clearly states that policy is a policy developed by agencies and government officials. This implication, he argues, implies: (1) that policy always has a particular purpose or is a goal-oriented action, (2) that the policy contains actions or patterns of actions of government officials, (3) that policy is What the government actually does, (4) that policy can be positive in the sense that it is some form of government action on a particular issue or is negative in the sense that it is a government official's decision not to do something, (5) that policy, Positive, based on legislation and is forcing (authoritative). In this sense, James E. Anderson states that policy is always related to what the government does or does not do.

\section{Professional development of Head of Madrasah}

Madrasah principals have a very important role in determining the whole wheels of school life or madrasah, by coordinating, mobilizing and utilizing all available educational resources. Headmaster or Madrasah leadership is a major 
factor in realizing the vision, mission and goals of schools or madrasah. The principal or Madrasah is required to have strong managerial and leadership skills in order to be able to make informed decisions to improve the quality of the school or madrasah. Nevertheless, the principal or Madrasah is not expected to be authoritarian but democratic, open and transparent, For other education personnel.7

Principal or Madrasah professionals act as supervisors, motivators, and organizers as well as managers. Whatever form of policy towards education both nationally and locally, the role of headmaster and Madrasah will not be released. This is because the headmaster or Madrasah is directly at the implementation stage of the policy. The success of education at the school or Madrasah level is determined by the principal or Madrasah in coordinating, mobilizing and aligning all available educational resources. Leadership of the principal or Madrasah to be able to Realizing the vision, mission, goals and objectives of the school or Madrasah through programs implemented in a planned and gradual manner. Therefore, the principal or Madrasah is required to have strong management and leadership skills to be able to take decisions and initiatives to improve the quality of schools or Madrasah.

For that purpose, the principal must be able to mobilize school resources, in relation to the planning and evaluation of school or Madrasah programs, curriculum development, learning, manpower management, learning resources and facilities, finance, student services, school relations or Madrasah with the community, and Creating a school climate or madrasah. ${ }^{8}$

The task of the principal or Madrasah as a supervisor is to help the teacher in two ways, namely: first, the development and improvement of the teaching profession, the two coaching and improvement of personal attitudes and professional attitude. The duties of Head of Madrasah can be described in detail as follows:

1. Assist teachers in understanding teaching and learning strategies.

2. Assist teachers in formulating learning objectives.

3. Assist teachers in compiling various learning experiences

4. Assist teachers in arranging learning activities

\footnotetext{
${ }^{7}$ Mulyasa, Kurikulum Berbasis Kompetensi :Konsep, Karakteristik dan Implementasi( Bnadung: RemajaRosdaKarya, cet ke-6, 2004), 150.

IIbid.
} 
5. Assist teachers in improving basic teaching skills

6. Assist teachers in managing the class and dynamize the class as a group process

7. Assist teachers in solving the problem of complaints

8. Assist teachers in solving welfare problems. ${ }^{9}$

Beside as organizer and supervisor, Head of Madrasah is also as a manager. $\mathrm{He}$ is a manager at Madrasah; he leads Madrasah based on Management, a professional Head of Madrasah should be able to place himself as a manager. In a Madrasah Based Manajemen, a Head of Madrasah at least must master the components of management of Madrasah, namely

1. Curriculum Management and Teaching Program

2. Management of Education Personnel

3. Student Management

4. Financial Management and Financing.

5. Facilities and Infrastructure Management

6. School Relationship Management with Community.10

An extra ordinary Head of Madrasah has high self-esteem, both to themselves and to the staff. This self-belief becomes the power to develop the school. In the uncertain school situation and the many problems faced, the extraordinary principal has trust Full and no doubt that all the problems can be solved well.

Outstanding school principals are always achievement oriented. . Besides always trying to improve ability and meet the standard of excellence. The orientation to the achievement is related to the achievement of the students. With respect to achievement-oriented, the principal's responsibilities according to Marzano in Williams, HW include:

1. Agent of change, willing to reject the current status quo;

2. Discipline, which protects teachers from issues and influences that will disturb their time and concentration in teaching;

3. Focus on setting clear goals and pioneering the school's attention;

4. Monitoring or evaluation, ie monitoring school practice activities and their impact on student learning; 
5. Resources, which is to provide teachers and professional development materials necessary for the successful implementation of their work.

An extra ordinary Head of Madrasah always has the initiative, seek opportunities, and seek information to advance the school he leads. In doing his actions, hedos not have to wait for orders from superiors. Even dare to simplify the bureaucracy that rambling, the important creativity to advance the school can be implemented with good.

Outstanding school principals realize that school success can only be achieved when it is done with teamwork and collaboration of the various components present in the school. Tiim and collaboration work is embedded in five of 21 responsibilities identified by Marzano that correlate with student achievement. These include:

1. Affirmation, which recognizes and celebrates achievement and recognizes failure.

2. Communication by establishing strong communication channels between teachers and students, teachers with teachers, and students with students;

3. Culture foster togetherness and mutual trust;

4. Involve teachers in making important policies or decisions in schools;

5. Intellectual strimulation by always holding discussions with teachers and staff on a regular basis in relation to the current prevailing theories to improve the school.

Thus it can be concluded that the principal who has the competence of the principal is superior or extraordinary. These advantages will have an impact on improving the performance of the school he leads. A competent headmaster will succeed in leading the school because it has a number of abilities that can be applied in leadership.

\section{METHODOLOGY}

This research is descriptive research. In descriptive research research, the center of attention is to describe the circumstances being studied carefully. Thus this study aims to examine how the formulation, implementation, performance and evaluation of professional teacher quality development policy in Madrasah Aliyah Negeri 2 Model Medan by Head of Madrasah Aliyah Negeri 2 Model Medan. 
The type of research used to achieve the above objectives is qualitative research. According to Moleong, qualitative research is a study that intends to understand the phenomenon of what is experienced by the subject of research, such as behavior, perception, motivation, action and others. In this study information was collected from respondents by using directional interviews, of which data were collected from informants. Thus this type of research is qualitative research.

As explained by Burhan Bungin, qualitative research aims to illustrate, summarize the various conditions, situations, or variables that arise in society that becomes an object of research, then draws to the surface as a feature or description of a particular condition, situation or variable. This research is reviewed from the data obtained and the place of research is including field research, where researchers conduct research on the formulation, implementation, performance and evaluation of professional teacher quality development policy in Madrasah Aliyah Negeri 2 Model Medan by the Head of Madrasah Aliyah Negeri 2 Model Medan.

The qualitative approach focuses on the general principles underlying the embodiment of a meaning of social phenomena in society. Thus a study using a qualitative approach uses the treasures of empirical phenomena, such as case studies, personal experiences, life history, interviews, observation, history, interaction and visual texts as well as message content describing the routines and problems and the meaning of individual life. This study uses the approach of Islamic Education Management Science. Therefore, in the research process starting from the preparation of research proposal preparation, literature review, determining research methodology and delivery of research results used perspective of Management Science Education and Management of Islamic Education.

\section{Place and the Time of Research}

The location of this research is State Islamic Senior High School (MAN) 2 "Model" of Medan Medan. This location is chosen because in this Madrasah has its own uniqueness in terms of qualities that can be proud. The quality can be punched from several aspects, such as aspects of Human Resources (HR) of teachers, facilities and achievements of Madrasah principals and madrasah students.

The time planning used to complete this research is about 6 (six) months, ie starting from August 2015 until January 2016. 


\section{Data Sources}

The data source of this research consists of primary sources and secondary sources. Primary data sources are data obtained from the field of research directly, ie from informants by using data collection instruments. This is explained in the data collection instrument.

Secondary sources in this research is data obtained through library research (library research) that is by collecting data and reading books or documents related to management education and management of Islamic education.

\section{Research Informan}

Qualitative research aims to reveal qualitative information so that more emphasis on the process and meaning of the problem by way of describing a problem. The object of this research is the policy of Madrasah principal in developing the professional quality of teachers in Madrasah AliyahNegeri 2 Model Medan. Based on the obejekpenejlitian the informant in this study is the Head of Madrasah AliyahNegeri 2 Model Medan, Vice Principal Madrasah and teachers and employees in Madrasah AliyahNegeri 2 Model Medan

Informant research is someone who because have information (data) a lot about the object being studied, asked for information about the object of the study. Among the many informants, there are so-called "key informants" key informants-a person or a few people, who are the people or people who have the most information (most know) about the object being studied

\section{Technique to Analyze the Data}

In this study to produce a report done with inductive reasoning that can be done in three ways, namely generalizations, analogies, causal relationships (causation). Firstly, Generalization is a process of reasoning that departs from a number of similar symptoms or events to draw conclusions about all or some of the symptoms or events. Generalization is derived from specific symptoms obtained through experience, observation, interviews or documentation studies. The sources can be documents of the Head of Madrasah AliyahNegeri 2 Model Medan, Deputy 
Head of Madrasah and teachers, statistics and testimonies related to the quality development of Profesionalguru in Madrasah AliyahNegeri 2 Model Medan.

Secondly, it was by analogy. The analogy is done because something compared to the comparison has the same function or role. By analogy, the researcher can explain something abstract or complicated concretely and more easily digested. The analogy referred to here is an inductive analogy or logical analogy. Inductive analogy is a process of reasoning that departs from two special events or phenomena that each has similarities to draw a conclusion. Since the starting point of reasoning is a commonality between two things, the conclusion will imply that what applies to something will also apply to other things. Thus the basis of the conclusion used is a central feature or essence that is closely related to two analogous things. The researcher will do an analogy between the data obtained from the Laws and Regulations, data of Head of State Islamic Senior High School (MAN) 2 "Model" of Medan Medan, Deputy Head and Teacher.

Thirdly, is by causal relationship. According to the law of causality all the events occurring in the world are intertwined in a cause-and-effect sequence. No single symptom or event occurs without a cause. First, one or more of the symptoms may serve as cause or effect as a result of previous symptoms and causes The following symptoms. Secondly, the symptoms or events that occur can be caused by one or more causes, and result in one or more consequences. In this research will be tested whether the formulation or planning, implementation, performance and evaluation of Madrasah principal policy in developing the professional quality of teachers in Madrasah AliyahNegeri 2 Model Medan in accordance with existing theory and what innovation from head of Madrasah in development of professional quality of teacher at Madrasah AliyahNegeri 2 Model Medan. When done will be studied what the challenges and obstacles, and if not applied also clarified with the argument.

\section{FINDINGS AND DISCUSSION}

\section{Policy Formulation by Head of Madrasah in Quality Development of Teacher Professionalism. \\ In the view of the Head of Madrasah Aliyah Negeri 2 Model Medan professional teachers are:}


Professional teachers are teachers who have professional competence. Professional meaning that I think when a teacher designing lessons then he applied in the class without getting out of what he designed. This is one of the characteristics of a professional teacher. And if the teacher is able to carry out what he is programming and that is what he does in the classroom, God willing, learning will be successful. My view is about professionals. The second includes mastery of matter. So the material that is taught that he must understand and must be supplemented with the sources so that supported the learning process. ${ }^{11}$

From the perspective of the Head of State Islamic Senior High School (MAN) 2 "Model" of Medan above it is clear that what he understands is a professional teacher is a teacher who has professional competence. There are two indicators of professional teachers according to the Head of State Islamic Senior High School (MAN) 2 "Model" of Medan Medan, which is first able to design the learning before the implementation and able to carry out the lesson planning in the classroom. Second, master the material and understand it.

Related to the professionalism of teachers in Madrasah Aliyah Negeri (MAN) 2 Model, Head of Madrasah explained that: Alhamdulillah, the first standard determined by BSNP is seen from the qualifications of education, namely matching the subjects taught with teacher education background. So in Madrasah Aliyah Negeri 2 This model is alhamdulillah 95\% is already matchingfor the exact, social, religious subject is the same. For example he majored in chemistry at S1 then he here teaches chemistry. So it has fulfilled what is demanded by BSNP. ${ }^{12}$

\section{Analysis}

Before formulating policies to improve the quality of professionalism of teachers in State Islamic Senior High School (MAN) 2 "Model" of Medan, Head of Madrasah first conduct policy analysis. At least in a Madrasah there are several interrelated management components, namely curriculum and teaching program management, personnel management, student management, financial management and financing, facilities and infrastructure management, special service

11Dr. P. Burhanuddin Harahap, Head Master of MAN 2 Model Medan, Interview on January 15, 2017.

12 Dr. P. Burhanuddin Harahap, Head Master of MAN 2 Model Medan, Interview on January 15, 2017. 
management. Therefore, teachers are one component of the seven components of madrasah-based management.

At this stage of policy analysis there are several issues included in the agenda to be selected. There are issues defined as the focus of discussion, issues that may be delayed, or may not be at all. Each issue that is inserted or not included on the agenda has their respective arguments. The parties involved in the agenda setting should look carefully at any issues that have a high degree of relevance to the policy issue. So the election can find the right policy issues.

In this analysis study, Madrasah principals do not immediately know what are the problems in each component of madrasah management, including teacher issues. Therefore, prior to analyzing the needs of the next year, the head of madarasah collects a team work consisting of the Deputy Head of Madrasah, Head of Division, Treasurer and Administration, but sometimes the head of Madrasah directly collects all the heads of departments and fields and team work members.

It is in this team work meeting that the principal of Madrasah gives every field and component a chance to explain the problems he is facing in carrying out his duties and responsibilities. With the opportunity to convey the problems, the head of Madrasah knows what are the problems faced by each component of madrasah management, including teacher issues. In this meeting all those responsible for the Madrasah management component will address the problems that exist in the component. Deputy head of Madrasah curriculum field will present curriculum issues, student field will convey student problems, infrastructure and finance as well as special services will also convey the problems that are being faced. All parties will address the problems they face.

Based on the results of this meeting then the head of Madrasah will know all the problems that are faced by each component. Head of Madrasah will inventory all these problems so that it becomes one unity that will be made into a work program. Although a problem faced has not yet become a program to be completed, but the head of Madrasah already knows the smallest to the greatest problem. Opportunities to convey problems and opportunities to give opinions are invaluable for teachers and education personnel for heads of Madrasahs to listen. The head of Madrasah will select the problems that exist with the priority scale that must be completed. 
The illustration stages of proposing the idea of teacher development for professional quality policy can be seen as the following picture:

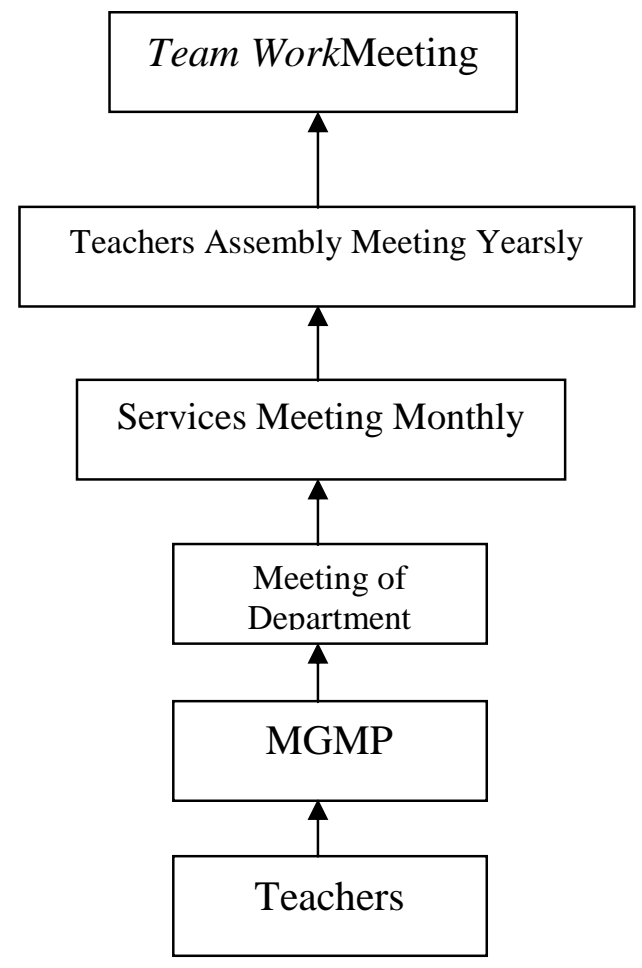

Process of Composing Stage dea of Teacher Professionalism Development Policy In State Islamic Senior High School (MAN) 2 "Model" of Medan Medan

\section{Developing the Program}

The program for one-year was formulated based on the vision, mission and education motto that has been formulated. Vision of State Islamic Senior High School (MAN) 2 "Model" of Medan is "Islamy, Integrity, Prestation dan Care to the Invironment". This vision was formulated in the following missions:

1. Organizing learning and training process based on akhlakul karimah and achievement.

2. Organizing the learning process and training of Indonesian character

3. Organizing the learning process and the environment nuanced exercise.

4. Organizing the process of learning and training systematically and technologically 
5. Organizing learning and training process based on research and development.

Based on the results of interviews and observations made, the vision and mission above are formulated in the work program. A one-year work program to develop the professionalism of teachers in State Islamic Senior High School (MAN) 2 "Model" of Medan is: 1) Provide budget, 2) Provide Motivation, 3) Comparative Study, 4) Providing an Opportunity to Publish a Book, 5) Motivate teachers to continue their education to a higher level.

\section{The Policy of Teachres Development of Professeionalism}

One of the most interesting from the organization of the State Islamic Senior High School (MAN) 2 "Model" of Medan is the establishment of the Teacher Performance Appraiser and Head of International Relations. The Head of Teacher Performance Appraisal is responsible for assisting teachers in performing their duties. He served: 1) Providing services to teachers to assist the implementation of tasks, 2) Assess the teacher, 3) Review and analyze the problems faced by teachers, 4) Documenting all data of teachers and their activities.

Establishing the field of Performance Appraisers The teacher helps the principal to formulate, organize, implement all policies relating to teachers and evaluate them. This field will continue to serve the teacher to do his job. He is not only tasked to monitor and assess teachers so that teachers feel burdened, but the main task is to provide services to teachers to be assisted in carrying out their duties. Officials who sit in this field are senior teachers who have been paid service from civil servants, so he does not have a burden in carrying out the task. He will give his experiences to teachers who are having problems in the execution of tasks. In essence this structure is the main role for the teacher consultant in the execution of its duties.

In addition to being a consular, this field is also tasked with providing teacher performance assessments. In the science of management affirmed that reward and punishment is very important for a teacher or anyone who performs the task. This field will collect data of teacher success in performing duties and discipline violation. The criteria that will be assessed by this field are:

1. Teacher attendance level in performing tasks;

2. Completeness of all teacher's infrastructure before performing the task;

3. Teacher attendance levels in official meetings; 
4. Teacher attendance levels in events related to teacher quality improvement, such as MGMP meetings, congregation meetings, education and training events, workshop events, teacher workshops and so on.

5. Teacher discipline level in regulation for teachers; Such as clothing, delays, discipline of teachers in handing over tasks on time, such as hand over questions for exams and scoring.

\section{Implementation of Quality Development and Teacher Professionalism Policy.}

Specifically related to the development of teacher professionalism quality in State Islamic Senior High School (MAN) 2 "Model" of Medan, there are some indicators of Madrasah heads that are able to lead teachers and staff in the framework of optimal utilization of human resources as follows::

1. Able to communicate the school's vision, mission, goals, goals and programs to the overall teacher and staff.

2. Able to coordinate teachers and staff in realizing the overall plan to achieve the vision, develop a mission, reach the goals and objectives of the school.

3. Able to communicate, provide direction of assignment, and motivate teachers and staff to carry out their main tasks and functions in accordance with the standard operational procedure set.

4. Able to build teamwork between teachers, teachers, and teachers with staff in advancing the school.

5. Able to equip teachers and staff with professional skills so that they can see for themselves what needs to be done in accordance with their respective tasks and functions.

6. Be able to equip staff with skills so that they can see for themselves what is necessary and updated for school progress.

7. Be able to lead meetings with teachers, staff and parents of students and school committees.

8. Be able to execute decision making by using the right strategy.

9. Be able to implement conflict management. ${ }^{13}$

${ }^{13}$ Ibid. 
Based on the indicators above, it was clear that the Head of State Islamic Senior High School (MAN) 2 "Model" of Medan is as a leader for teachers and employees. Head of Madrasah Aliyah was able to carry out all the indicators above. It looks at his ability to communicate, coordinate, motivate, co-operate, guide, train, make decisions and implement conflict management. Head of State Islamic Senior High School (MAN) 2 "Model" of Medan is able to communicate well to the teacher. He always strives for good communication, effective and efficient. He is also able to coordinate with the organ of Madrasah organization in State Islamic Senior High School (MAN) 2 "Model" of Medan, such as empowerment of Madrasah Deputy Head, Teacher Performance Assessment and other structures. He is able to divide the task according to his organs. Head of State Islamic Senior High School (MAN) 2 "Model" of Medan is also able to guide and train teachers to be more creative and independent by presenting expert resource and mastering problems faced by teachers in the form of seminars, workshops, education and training (training), Coffee morning, office meetings, MGMP rapport, Teacher Consultative meeting in the Department and others. All this is done in the rangkan to train and guide teachers to be more professional in carrying out the task. The head of Madrasah is also capable of creating conflict management so as to create a safe and peaceful atmosphere in performing the task. Deputy Head of Madrasah Public Relations explained that there was a conflict between teachers so that interfere with the performance of teachers. The principal of Madrasah does not allow it to continue so that he calls on the conflict parties to explain the root of the problem. When a dialogue is held between conflicting teachers, the head of Madrasah can find the problem and find the right solution. Madrasah principals strive to make good communication in order to avoid conflicts so that security and comfort in performing their duties arise. All organ organizations of the State Madrasah Aliyah (MAN) 2 Model has clear duties and functions.

\section{CONCLUSION}

The conclusion of this research is:

1. The formulation of policies undertaken by the Head of the State Madrasah Aliyah (MAN) 2 Model Medan for the professional development of teachers is a bottom up, whereas the idea of improving the quality of teachers comes from 
below, the teacher itself. Ideas derived from the results were obtained at the Subject Teachers' Meeting (MGMP), the teacher's deliberations at the majors, the deliberations at the monthly service meetings and the annual teacher assembly deliberations. All of these ideas are accommodated at each level of deliberation and will be delivered to a higher level. The results of teacher deliberations for the development of professional professionals were presented last at the annual teacher assembly meeting for the one-year program. These results are formulated again in the team work to determine the time and cost and technical procedures. Thus, any formulation of Madrasah principal policy for professional quality development always comes from the teacher. As an example of its policy to improve the professional quality development of teachers is to conduct teacher training every Saturday, the existence of training or workshop for teachers, seminars, comparative studies to universities and other educational institutions that will serve as a source of inspiration and also publish a handbook by teachers. In addition, teachers' professional quality improvement program is not only a direct program, but also things that support the performance of teachers, such as Kamra Madi or WC facilities teachers and the necessary tools, such as infocus, laptops and so forth. All the supportive needs for the implementation of teacher duties also come from the teacher.

2. Organizing the development of professional professionals in Madrasah Aliyah Negeri 2 Medan Model is supported by the formulation of the policy mentioned above. Structurally, the Madrasah Principal has established a well-established and well-established Madrasah organizational structure for the professional development of teachers. The organizational structure of the Madrasah head coordinates well to the Madrasah committee and the principal of Madrasah in performing its duties assisted by deputy heads of Madrasah curriculum field, student field, equipment field, and public relations field. While technically, the head of Madrasah is assisted by the field of teacher performance assessment, the field of each majors of study program, the field of foreign relations and the field of management of zakat, infak and alms. To cope with the problems of students in the classroom and outside the classroom, the head of Madrasah is assisted by the homeroom teacher. As for the relationship to the students, the head of Madrasah issued a decree (SK) for the appointment of the Chairman of the Class, 
so that the head of Madrasah can also directly communicate with the students regarding the implementation of the teacher's job in and out of the classroom.

3. Performance of Head of Madrasah Aliyah Negeri 2 Medan Model for professional development of teachers is to implement their duties and functions. He made himself a teacher, teacher leader, teacher manager, teacher motivator, teacher facilitator and teacher supervisor. These six functions are performed by the head of Madrasahs to improve and develop professional mutuprofesional teachers. It not only performs its duties and functions as a leader, but all of the above functions are run simultaneously. He carries out his duties as a leader, so the teacher must obey the rules, when he performs his function as a motivator so he gives motivation to the teacher to perform the task as well as possible, when he runs the tuga as manager, so he puts and assigns the teacher according to his field and his ability When he puts himself in as a facilitator, he prepares everything the teacher needs in order to carry out the task, and when he is the supervisor he supervises the teacher's performance.

The evaluation conducted by the head of Madrasah on the professional quality improvement policy of teachers in Madrasah Aliyah Negeri 2 Medan Model is every level of policy making and policy formulation. Evaluation is done at the level of Subject Teachers' Meeting (MGMP), evaluation on teacher training at department level, evaluation at monthly service meeting level, evaluation at annual teacher assembly meeting and evaluation at team work level. The evaluation is carried out according to the level.

\section{REFERENCES}

Danim, danSuparno, (2009).Manajemen dan Kepemimpinan Transformasional Kekepala Sekolaha; Visi dan Strategi Sukses Era Teknologi, Situasi Krisis dan Internasionalisasi Pendidikan. Jakarta: RinekaCipta

Suhardiman, S. (2012). Studi Pengembangan Kepala Sekolah; Konsep dan Aplikasi. Jakarta: Rineka Cipta.

Mulyasa, E. (2004). Kurikulum Berbasis Kompetensi: Konsep, Karakteristik dan Implementasi. Bnadung: Remaja Rosda Karya

Mulyasa, E. (2002). Manajemen Berbasis Sekolah. Bandung: Remaja Rasindo. 